e-Jurnal Ilmiah BIOSAINTROPIS (BIOSCIENCE-TROPIC)

Volume : 7/ No : 1 / Halaman 91 - 96 / Agustus Tahun 2021

ISSN : 2460-9455 (e) - 2338-2805(p)

\title{
Distribusi dan Frekuensi Alel Golongan Darah Sistem ABO dan Rhesus pada Penduduk di Pulau Gili Ketapang Probolinggo
}

\author{
Distribution and Allele Frequency of ABO Blood Group and Rhesus \\ in Population of Gili Ketapang Island, Probolinggo
}

\author{
Kirana Eka Rezki $\left.{ }^{1}{ }^{*}\right)$, Rike Oktarianti ${ }^{2}{ }^{* *}$, Hidayat Teguh Wiyono3, Purwatiningsih ${ }^{4}$ \\ Jurusan Biologi FMIPA Universitas Jember, Indonesia
}

\begin{abstract}
ABSTRAK
Sistem penggolongan darah pada manusia yang banyak dikenal adalah sistem ABO dan rhesus. Tujuan penelitian ini adalah mengetahui distribusi golongan darah sistem ABO dan rhesus serta frekuensi alel pada populasi penduduk pulau Gili Ketapang, kabupaten Probolinggo. Pengambilan sampel dilakukan dengan metode Slide Test dan dilakukan secara acak dengan cara melakukan pengundian jumlah sampel yang diambil sebanyak 384 jiwa. Identifikasi golongan darah sistem ABO pada penelitian ini dilakukan dengan metode slide dengan prinsip antigen (aglutinogen) yang direaksikan dengan antibodi (aglutinin). Hasil penelitian menunjukkan distribusi golongan darah sistem ABO dan Rhesus O+ (46,61\%), B+ (24,22\%), A+ (23,18\%), dan $\mathrm{AB}+(5,99 \%)$. Frekuensi alel IA $(0,16)$, frekuensi alel IB $(0,16)$, frekuensi alel i $(0,68)$, dan frekuensi alel rhesus positif $(\mathrm{Rh}+)$ adalah 1 . Proporsi fenotip dan frekuensi alel tertinggi adalah golongan darah $\mathrm{O}$ untuk sistem penggolongan darah ABO. Sedangkan untuk penggolongan berdasarkan rhesus diperoleh seratus persen rhesus positif. Data tersebut menunjukkan bahwa persebaran golongan darah $\mathrm{O}$ dan rhesus positif pada penduduk pulau Gili Ketapang relatif sama dengan hasil penelitian lain di Indonesia.
\end{abstract}

Kata kunci: Golongan Darah, ABO, Rhesus

\begin{abstract}
The most recognized blood group systems in human are the ABO and Rhesus system. The purpose of this study was to determine the distribution of $A B O$ and rhesus blood groups and allele frequencies in the population of Gili Ketapang Island, Probolinggo. Sampling was carried out using the Slide Test method and was carried out randomly by drawing lots, the number of samples taken was 384 people. The identification of the blood group of the $A B O$ system in this study was carried out using the slide method with the principle of antigen (agglutinogen) reacted with antibody (agglutinin). The results showed the distribution of blood group systems $A B O$ and Rhesus $O+(46.61 \%), B+(24.22 \%), A+(23.18 \%)$, and $A B+(5.99 \%)$. The frequency of the IA allele (0.16), the IB allele frequency (0.16), the $i$ allele frequency (0.68), and the positive rhesus allele frequency (Rh+) are 1 . The highest proportion of phenotypes and allele frequencies is type $O$ blood in the ABO blood group system. While the classification based on rhesus shows one hundred percent positive rhesus. This shows that the distribution of blood type $O$ and rhesus positive on the inhabitants of the Gili Ketapang island was similiar to other studies in Indonesia.
\end{abstract}

Keywords: $A B O$ and Rhesus blood groups

\footnotetext{
*) Kirana Eka Rezki, Jurusuan Biologi FMIPA UNEJ. JL. Kalimantan 37, Jember,

**) Rike Oktarianti, Jurusan Biologi FMIPA UNEJ, JL. Kalimantan 37 Jember.

Email : rike.fmipa@unej.ac.id
}

doi: 10.33474/e-jbst.v7i1.452

Diterima tanggal 25 Agustus 2021- Diterbitkan Tanggal 31 Agustus 2021 http://creativecommons.org/licenses/by/4.0 


\section{Pendahuluan}

Gili Ketapang merupakan satu-satunya desa yang terletak di Pulau Gili, yaitu sebelah utara Kabupaten Probolinggo, Provinsi Jawa Timur (Juniarta. et al., 2013). Pulau Gili Ketapang dihuni oleh penduduk suku Madura dengan jumlah penduduk mencapai 9.672 jiwa (Dinas Lingkungan Hidup, 2018). Populasi suku Madura masih menjunjung tinggi nilai adat istiadat di daerah setempat, salah satunya adalah adat tentang pernikahan . Pernikahan dengan satu suku ini masih berlangsung di populasi etnis Madura di pulau ini, hampir 90\% masyarakatnya melakukan perkawinan dalam satu suku. Hal ini bertujuan untuk mempertahankan keutuhan ikatan persaudaraan dan menjaga hubungan kekerabatan (Subhan,2020).

Perkawinan dalam satu suku dan dalam lingkup wilayah yang sama ini termasuk dalam kategori perkawinan endogami atau perkawinan tertutup. Perkawinan endogami merupakan perkawinan yang dilakukan dalam satu suku, etnis, klan, dalam satu lingkungan yang sama (Budilová, 2020). Salah satu faktor terjadinya perkawinan endogami karena faktor geografis. Wilayah Pulau Gili Ketapang yang susah dijangkau menjadikan tempat ini terisolasi sehingga interaksi populasi dengan suku lain sulit dilakukan (Rochmawati, 2016). Perkawinan sistem tertutup atau endogami akan berdampak terhadap peningkatan homosigositas dan penurunan variasi genetik atau heterosigositas (Yudianto. et al., 2017). Perkawinan tertutup dapat menyebabkan orang tua mewariskan gen identik atau gen yang bersifat homozigot kepada anaknnya (Marchi, et al., 2018). Salah satu sifat genetik yang diwariskan oleh orang tua adalah golongan darah. Golongan darah diwariskan dari orang tua ke anaknya tidak dipengaruhi oleh faktor lingkungan luar (Maatoghi, et al., 2016)

Sistem penggolongan darah pada manusia yang banyak dikenal adalah sistem ABO dan rhesus (Maatoghi, et al., 2016). Golongan darah sistem ABO pada manusia dibagi menjadi 4, yaitu golongan darah A, B, O dan AB (Oktari \& Silvia, 2016). Pengelompokan golongan darah ini tergantung pada jenis antigen yang ada pada permukaan sel darah merah (Shadia \& Hossain, 2018). Golongan darah sistem ABO ini ditentukan oleh tiga macam alel, yaitu alel $\mathrm{I}^{\mathrm{A}}, \mathrm{I}^{\mathrm{B}}$, dan alel $\mathrm{i}$. Alel $\mathrm{I}^{\mathrm{A}}$ dan alel $\mathrm{I}^{\mathrm{B}}$ bersifat dominan terhadap alel $\mathrm{i}$. Alel $\mathrm{I}^{\mathrm{A}}$ tidak dominan terhadap alel $\mathrm{I}^{\mathrm{B}}$ begitupun sebaliknya alel $\mathrm{I}^{\mathrm{B}}$ tidak dominan terhadap alel $\mathrm{I}^{\mathrm{A}}$, sehingga alel $\mathrm{I}^{\mathrm{A}}$ dan $\mathrm{I}^{\mathrm{B}}$ disebut kodominan (Irawan, 2010). Keberadaan alel tersebut mampu menyebabkan pewarisan golongan darah sistem ABO menghasilkan individu dalam keadaan homozigot atau heterozigot (Denise,2005).

Selain golongan darah sistem ABO terdapat penggolongan darah pada manusia berdasarkan rhesus. Golongan darah sistem rhesus merupakan penggolongan darah berdasarkan ada atau tidaknya antigen-D di dalam sel darah merah. Rhesus terdiri dari dua komponen yaitu Rhesus positif (RH+), dan rhesus negatif ( $\mathrm{RH})$. Golongan darah rhesus positif jika di dalam darah terdapat antigen-D dan sebaliknya golongan darah rhesus negatif jika di dalam darah tidak terdapat antigen-D (Haqq, 2018).

Melihat kondisi wilayah dan geografi Pulau Gili Ketapang yang merupakan daerah terpencil, menyebabkan penduduk cenderung melakukan perkawinan tertutup atau endogami. 
Penelitian terdahulu pernah dilakukan oleh Puspito (2004) di Pulau Gili Ketapang Probolinggo, menghasilkan data distribusi golongan darah sistem ABO tertinggi adalah golongan darah O. Maka penelitian terkait distribusi golongan darah ABO dan rhesus, pada penduduk desa Gili Ketapang Probolinggo menarik untuk dilakukan kembali. Hal ini bertujuan untuk melihat apakah terjadi perubahan pada proporsi fenotip dan frekuensi alel golongan darah sistem ABO dan rhesus selama kurun waktu 17 tahun sejak terakhir dilakukan peneltian.

\section{Metode}

Penelitian dilakukan pada bulan April - Juni 2021, di Desa pulau Gili Ketapang kabupaten Probolinggo. Pengambilan sampel dilakukan secara acak dengan cara dilakukan pengundian. Jumlah sampel yang diambil sebanyak 384 jiwa merupakan penduduk asli Pulau Gili Ketapang yang melakukan perkawinan endogami dan keturunannya. Identifikasi golongan darah sistem ABO pada penelitian ini dilakukan dengan metode slide test dengan prinsip antigen (aglutinogen) yang direaksikan dengan antibodi (aglutinin) (Guyton dan Hall, 2019). Pengambilan sampel yang dilakukan mengikuti prosedur yang disetujui dan diterbitkan oleh Komisi Etik, Fakultas Kedokteran Gigi, Universitas Jember dengan nomor Ethical Clearance 1224/UN25.8/KEPK/DL/2021.

Parameter penelitian meliputi penghitungan proporsi fenotip golongan darah sistem $\mathrm{ABO}$ dan frekuensi alel $\mathrm{I}^{\mathrm{A}}, \mathrm{I}^{\mathrm{B}}$, i dan alel rhesus.

Menghitung proporsi fenotip golongan darah sistem $\mathrm{ABO}$ yaitu menghitung proporsi golongan darah $\mathrm{O}, \mathrm{A}, \mathrm{B}$ dan $\mathrm{AB}$ dengan rumus.

$$
\text { fenotip }=\frac{\text { Jumlah individudengan fenotipe tertentu dalam populasi }}{\text { Jumlah Sampel dalam suatu Populasi }} \times 100 \%
$$

Frekuensi alel IA, IB, dan i pada golongan darah sistem ABO dihitung menggunakan rumus.

$$
\left(p^{2} I^{A} l^{A}+2 p r I^{A} i+q^{2} I^{B} l^{B}+2 q r l^{B} i+2 p q I^{A} l^{B}+r^{2} i i\right)=1
$$

\section{Hasil dan Diskusi}

Proporsi fenotip golongan darah sistem ABO dan rhesus pada penduduk desa Gili Ketapang Probolinggo dan data pembanding dari PMI Kabupaten Probolinggo dapat dilihat pada Tabel 1.

\begin{tabular}{|c|c|c|c|c|c|c|c|}
\hline \multirow{2}{*}{$\begin{array}{c}\text { Golongan } \\
\text { Darah }\end{array}$} & \multirow[b]{2}{*}{ Rhesus } & \multicolumn{2}{|c|}{ Gili Ketapang 2021} & \multicolumn{2}{|c|}{ Gili Ketapang 2004} & \multicolumn{2}{|c|}{ Data PMI } \\
\hline & & Jumlah & $\begin{array}{c}\text { Persentase } \\
(\%)\end{array}$ & Jumlah & $\begin{array}{c}\text { Persentase } \\
(\%)\end{array}$ & Jumlah & $\begin{array}{c}\text { Persentase } \\
(\%)\end{array}$ \\
\hline A & + & 89 & 23,18 & 66 & 18,8 & 81 & 20,30 \\
\hline B & + & 93 & 24,22 & 100 & 28,5 & 119 & 29,83 \\
\hline$A B$ & + & 23 & 5,99 & 12 & 3,41 & 31 & 7,77 \\
\hline o & + & 179 & 46,61 & 173 & 49,29 & 168 & 42,10 \\
\hline \multicolumn{2}{|c|}{ Total } & 384 & 100 & 351 & 100 & 399 & 100 \\
\hline
\end{tabular}

Tabel 1. Proporsi fenotip golongan darah sistem ABO pada penduduk GiliKetapang dan data Pembanding PMI

Tabel 1 menunjukan data persentase hasil dari perhitungan proporsi fenotip penduduk Gili Ketapang tahun 2004, 2021 dan data pembanding dari PMI Kabupaten Probolinggo. Dilihat dari Tabel 4.1 menunjukan bahwa ada sedikit perbedaan dengan data tahun 2004. Data Tahun 2004 digunakan untuk membandingkan atau melihat adanya perubahan pada proporsi fenotip dan frekuensi alel selama 17 tahun dilakukan penelitian ditempat yang sama. Jumlah individu dengan golongan darah B lebih tinggi terpaut jauh dari data 2021. Data 2021 menunjukan bahwa individu yang bergolongan darah A dan B memiliki persentase yang hampir sama. Hal ini menunjukkan dalam kurun waktu 17 tahun jumlah penduduk yang memiliki golongan darah A mengalami peningkatan dan sebaliknya golongan darah B mengalami penurunan persentase. Demikian juga untuk 


\section{e-Jurnal Ilmiah BIOSAINTROPIS (BIOSCIENCE-TROPIC)}

Volume : 7/ No : 1 / Halaman 91 - 96 / Agustus Tahun 2021

ISSN : 2460-9455 (e) - 2338-2805(p)

persentase golongan darah $\mathrm{AB}$ mengalami peningkatan sedangkan golongan $\mathrm{O}$ terjadi penurunan persentase. Perbedaan persentase ini dapat disebabkan beberapa faktor salah satunya adalah faktor migrasi. Berdasarkan hasil survei penduduk Gili Ketapang sering melakukan mobilitas dari dalam dan keluar pulau.

Tabel 1 menunjukkan bahwa persentase proporsi fenotip tertinggi adalah golongan darah O baik pada penduduk pulau Gili Ketapang maupun data PMI Probolinggo. Data PMI dan data hasil penelitian di Pulau Gili Ketapang menunjukan angka yang berbeda hal ini dapat dikarenakan lokasi pengambilan sampel yang berbeda, tetapi secara pola distribusi golongan darah sistem ABO pada penduduk Gili dan data pembanding dari PMI Kabupaten Probolinggo hampir sama yaitu urutannya O, B, A, AB. Pola distribusi golongan darah dengan urutan O, B, A, AB secara umum sering dijumpai di Indonesia (Kemenkes RI, 2018).

Hasil pemeriksaan Rhesus, semua penduduk Pulau Gili Ketapang Kabupaten Probolinggo memiliki Rhesus Positif (+) dan tidak dijumpai adanya Rhesus Negatif (-), hal ini karena golongan darah rhesus negatif (Rh-) hanya ditemukan sekitar $15 \%$ pada ras kulit putih, sedangkan pada ras Asia jarang dijumpai rhesus negatif, kecuali terjadi perkawinan campuran dengan orang asing yang bergolongan rhesus negatif (Arosa,2016) Berdasarkan data dari Kemenkes RI (2016) di Indonesia jumlah frekuensi alel Golongan darah Rhesus Positif mencapai 99\%, dan frekuensi alel golongan darah Rhesus negatif hanya $0,1 \%$.

Frekuensi alel golongan darah sistem ABO pada populasi pulau Gili Ketapang dan data pembanding PMI Kabupaten Probolinggo dapat dilihat pada Tabel 2.

Tabel 2. Frekuensi alel golongan darah sistem ABO penduduk pulau Gili Ketapang dan data PMI

\begin{tabular}{cccc}
\hline \multirow{2}{*}{ Alel } & \multicolumn{3}{c}{ Frekuensi Alel } \\
\cline { 2 - 4 } & Gili Ketapang 2021 & Gili Ketapang 2004 & Data PMI \\
\hline I $^{\mathrm{A}}$ & 0,16 & 0,12 & 0,13 \\
I $^{\mathrm{B}}$ & 0,16 & 0,17 & 0,22 \\
i & 0,68 & 0,70 & 0,65 \\
Total & 1 & 1 & 1 \\
\hline
\end{tabular}

Berdasarkan Tabel 2. dapat dilihat frekuensi alel golongan darah penduduk Gili Ketapang dan Data PMI Kabupaten Probolinggo. Nilai frekuensi alel populasi pulau Gili Ketapang yang dilakukan pada tahun 2021 sedikit berbeda dengan penelitian yang dilakukan oleh Agung Puspito (2004). Perbedaan terjadi pada frekuensi alel $\mathrm{I}^{\mathrm{A}}$ dan $\mathrm{I}^{\mathrm{B}}$. Sedangkan frekuensi alel i data 2021 dan 2004 relatif sama. Perbedaan frekuensi alel $\mathrm{I}^{\mathrm{A}}$ dan $\mathrm{I}^{\mathrm{B}}$ dapat terjadi, hal ini diduga dipengaruhi oleh beberapa faktor. Menurut Iza (2017), adanya migrasi dan perkawinan acak yang dapat mempengaruhi frekuensi alel. Diduga selama kurun waktu 17 tahun telah terjadi migrasi dan perkawinan acak yang menyebabkan perubahan pada frekuensi alel golongan darah sistem ABO. Jika terjadi migrasi ke dalam maka terjadi penambahan alel tertentu sedangkan jika migrasi keluar maka terjadi pengurangan alel tertentu dari suatu populasi.

Jika dibandingkan dengan data PMI, menunjukkan ada perbedaan pada frekuensi alel IA dan IB, namun untuk alel i frekuensi relatif sama. Perbedaan frekuensi alel $\mathrm{I}^{\mathrm{A}}, \mathrm{I}^{\mathrm{B}}$ diduga dipengaruhi perbedaan lokasi pengambilan sampel. Frekuensi alel i lebih tinggi dari frekuensi alel lainnya baik pada populasi Pulau Gili Ketapang maupun data PMI Kabupaten Probolinggo, hal ini karena alel i terdapat pada hampir semua golongan darah. Menurut Campbell et al (2010) alel i terdapat pada golongan darah A heterozigot, golongan darah B heterozigot dan golongan darah $\mathrm{O}$. Jumlah sampel yang bergolongan darah O lebih tinggi daripada golongan darah lainnya oleh karena itu golongan darah $\mathrm{O}$ menyumbangkan alel i terbanyak.

Golongan darah lain yang diperiksa adalah golongan darah sistem rhesus. Hasil pemeriksaan golongan darah sistem rhesus penduduk Gili Ketapang semuanya memiliki golongan darah positif. Hal ini didukung data dari Kemenkes RI (2018) yang menyatakan hampir 99\% penduduk Indonesia memiliki golongan darah dengan rhesus positif. Frekuensi alel rhesus dapat dilihat pada tabel 3 yang menunjukan bahwa frekuensi alel rhesus positif adalah 1. Frekuensi golongan darah rhesus berbeda-beda pada berbagai suku bangsa, namun semua negara rata-rata memilki frekuensi alel rhesus positif yang lebih tinggi dibandingkan rhesus negatif (Suryo, 2012). Hal ini didukung oleh beberapa penelitian yang telah dilakukan di beberapa negara seperti negara Maroco yang memiliki nilai frekuensi alel golongan darah rhesus positif 0,91 dan golongan darah rhesus negatif 0,09 (Benahadi, 2018).

Tabel 3. Frekuensi alel Golongan darah sistem Rhesus

\begin{tabular}{lcccc}
\cline { 2 - 4 } & \multicolumn{4}{c}{ Rhesus } \\
\cline { 2 - 5 } Blel & $\begin{array}{c}\text { Populasi Pulau Gili } \\
\text { Ketapang }\end{array}$ & Data PMI \\
\hline $\mathbf{R}$ & 1 & 1 & 94 \\
$\mathbf{r}$ & 0 & 0 & \\
& Total & 1 & 1 & \\
\cline { 2 - 5 } & & &
\end{tabular}




\section{Kesimpulan}

Distribusi golongan darah sistem ABO dan Rhesus pada populasi Pulau Gili Ketapang Kabupaten Probolinggo yang mayoritas melakukan perkawinan endogami berturut-turut sebagai berikut, $\mathrm{O}+(46,61 \%), \mathrm{B}+(24,22 \%), \mathrm{A}+(23,18 \%)$, dan $\mathrm{AB}+(5,99 \%)$. Frekuensi alel golongan darah sistem ABO dan rhesus pada populasi Pulau Gili Ketapang Kabupaten Probolinggo adalah frekuensi alel IA $(0,16)$, frekuensi alel IB $(0,16)$, dan frekuensi alel i $(0,68)$, dan frekuensi alel rhesus positif 1 .

\section{Ucapan Terima Kasih}

Penulis mengucapkan terimakasih kepada perangkat desa yang telah membantu pelaksanaan penelitian dan penduduk di desa pulau Gili Ketapang, kabupaten Probolinggo yang telah bersedia menjadi probandus dalam penelitian ini.

\section{Daftar Pustaka}

[1] Alimba, C. G., O. Khalid, Adekoya, O. Bola, dan Oboh. 2010. Prevalence and frequencies of Phenylthiocarbamide (PTC) Taste Sensitivity, ABO and rhesus factor (Rh) blood groups, and haemoglobin variants among a Nigerian Population. The Egyptian Journal of Medical Human Genetics. 11 (10): 153 - 158.

[2] Amania, N., H. T. Wiyono, dan R. Oktariani. 2020. Frekuensi alel golongan darah sistem A-B-O pada populasi Suku Osing Desa Kemiren Kabupaten Banyuwangi. Bioma. 5 (1): 11-21.

[3] Apecu, R. O., E. M. Mulogo, F. Bagenda, dan A. Byamungu. 2016. ABO and rhesus (D) blood group distribution among blood donors in Rural South Western Uganda: A retrospective study. BMC Research Notes. 9 (1): 1-4.

[4] Basu, D., Datta, S.S., M. Celina, B. Prasun, M. Krishnendu, dan F.A. Willy. 2017. ABO, Rhesus and Kell Antigens, Alleles and Haplotypes in West Bengal India. Transfusion Medicine and Hemotherapy. 45 : 62-66.

[5] Benahadi, A., R. Alami, S. Boulahdid, B. Adouani, A. Laouina, A. Mokhtari, A. Soulaymani, H. Khdija, dan M. Benajiba. 2013. Distribution of ABO and rhesus D blood antigens in Morocco. The Internet Journal of Biological Anthropology. 6(1): 1-6.

[6] Budilova, L. J. 2019. Endogamy Between Ethnicity and Religion. Marriage and Boundary Construction in voyvodovo (Bulgaria).

[7] Candra, T., G, Ashish. 2012. Prevalence of ABO and Rhesus Blood Group in Northern India. Blood Disorders \& Transfusion. 3 (5). 
e-Jurnal Ilmiah BIOSAINTROPIS (BIOSCIENCE-TROPIC)

Volume : 7/ No : 1 / Halaman 91 - 96 / Agustus Tahun 2021

ISSN : 2460-9455 (e) - 2338-2805(p)

[8] Chester, M. A. dan M. L. Olsson. 2001. The ABO blood group gene: A locus of considerable genetic diversity. Transfusion Medicine Reviews. 15 (3): 177-200.

[9] Christian, S.G., dan E. M. Eze. 2018. Haemoglobin genotype, ABO and rhesus blood group distribution in Briggs family of Abonema Rivers State, Nigeria. Asian Journal of Medicine and Health. 13(2): 1-8.

[10] Golassa, L., T. Arega, E. Berhanu, M. Haseen. 2017. High rhesus (Rh(D)) negative frequency and ethnic-group based $\mathrm{ABO}$ blood group distribution in Ethiopia. BMC research notes. 10 (1): 1-5.

[11] Hameed, A. H, Wajahat., A, Janbaz., R, Fazli., Q, A, Javed. 2002. Prevalence of Phenotypes and Genes of ABO and Rhesus (Rh) Blood Groups in Faisalabad, Pakistan. Pakistan Journal of Biological Scinces. 5 (6): 722-724.

[12] John, S. 2017. Prevalence of ABO and rhesus blood groups in blood donors: a study from a tertiary care Centre in South Kerala. Internasional Journal of Contemporary Medical Research. 4 (11): 77-83.

[13] Kumar, N., Kapoor, N., Kalwar, A., N, Satya., S, K, Mukesh., K, Akhender., M, Abhishek., B, R, Megh. 2014. Allele Frequency of ABO Blood Group Antigen and the Risk of Esophageal Cancer. Biomed Research Internasional.

[14] Maatoghi, J. T., M. Paridar, M. M. Shoushtari, B. Kiani, B. Nori, M. Syahjahani, A. Khosravi, N. A. Kelarijani, O. K. Ghalesardi, dan M. A. Jalali. 2016. Distribution og ABO blood groups and rhesus factor in a large scale study of different cities and Ethnicities in Khuzestan Province. Iran. Jurnal of Medical Human Genetic. 17 : 105109.

[15] Okpara, M. 2013. Frequency Distribution Of ABO, RH Blood Groups and Blood Genotypes Among the Student and Staff of Michael Okpara University of Agriculture, Umudike Abia State, Nigeria.

[16] Paul, G., U. Saloni, S. S. Chufal, Y. Hasan, dan I. Tayal. 2014. Prevalence og ABO and rhesus blood groups in blood donors: a study from a tertiary care teaching hospital of Kumaon Region of Uttarakhand. Journal of Clinical and Diagnostic Research. 8 (12): 16. 